\title{
SPIGOLON, Nima Imaculada; LEITE, Sandra Fernandes; PALMEN, Sueli; FABIANO, Edson; DRI, Wisllayne de Oliveira; SOUZA, Vanessa Cristina de (Orgs.). Reinventar a universidade: extensão universitária com a EJA. Uberlândia: Navegando Publicações, 2019.
}

Victor Hugo Nedel Oliveira ${ }^{1}$

Área Temática: Educação. Teorias e Metodologias em Extensão.

A extensão universitária caracteriza-se como sendo um dos tripés que sustentam a vida e a produção acadêmica, ao lado do ensino e da pesquisa. Para a comunidade em geral, a extensão tem sido a forma mais corriqueira pela qual a Universidade se faz presente em seu cotidiano, através das inúmeras, diversas, criativas e fundamentais estratégias extensionistas, seja a partir de programas, projetos ou ações de extensão. No âmbito da escola básica, a etapa de escolarização denominada Educação de Jovens e Adultos (EJA) trata-se de importante e basilar forma pela qual a educação e a escola chegam naqueles que, pelos mais variados motivos, não acompanharam o ensino regular e, apesar de tudo, desejam concluir os estudos referentes ao Ensino Fundamental e Médio.

A partir dessa contextualização, o objetivo central do presente texto é apresentar resenha crítica da obra "Reinventar a universidade: extensão universitária com a EJA", organizada por Nilma Spigolon et al e escrita por muitas mãos, em uma verdadeira autoria coletiva. A obra foi publicada em 2019, pela editora Navegando Publicações.

O livro, composto por 40 capítulos, está organizado em três partes, que apresentam resultados, discussões e reflexões a partir de três atividades de extensão universitária, realizadas a partir do trabalho dos seguintes grupos: o Grupo de Estudos e Pesquisas em Educação de Jovens e Adultos (GEPEJA), o Projeto Integrativo de Ação Social (PEIS) a Rede Articula Juventude (REAJU e NAED-Noroeste/GTEJANORO), vinculados à UNICAMP.

${ }^{1}$ Professor Adjunto e Pesquisador do Departamento de Humanidades da Universidade Federal do Rio Grande do Sul (UFRGS). Endereço: Av. Bento Gonçalves, 9500, prédio 43815, gabinete 210, Bairro Agronomia, Porto Alegre, RS, CEP: 91509-900 Telefone: (51) 3308-6984. E-mail: victor.juventudes@gmail.com 
Na primeira parte, intitulada: "Curso de extensão: fundamentos da educação de jovens, adultos e idosos - teoria e história", composta por vinte e oito textos, são apresentadas as bases teóricas do referido curso, em especial a partir das concepções de Paulo Freire. São apresentados oito artigos referentes aos componentes históricos, sociais, econômicos, políticos e pedagógicos presentes na trajetória dos sujeitos da Modalidade Educação de Jovens e Adultos e, ainda, vinte ricos textos em formatos de memoriais elaborados a partir das narrativas autobiográficas, vivências e percepções dos professores cursistas.

Na segunda parte, por sua vez, denominada: "Curso de extensão educação, juventude política e ações afirmativas", composta por sete textos, que buscaram, a seu modo, aprofundar conceitos-chave sobre o campo das juventudes; conhecer as políticas públicas para as juventudes; debater alguns dos estudos sobre a pedagogia Freireana e compartilhar as metodologias de trabalho do curso referido.

A terceira parte, por fim, chamada de: "Projeto ilustrando o mundo pela EJA", composta por cinco textos, que puderam socializar as artes produzidas pelos sujeitos estudantes e professores das escolas participantes do projeto, além de apresentar o trabalho pedagógico desenvolvido a partir dessas intervenções e publicizar algumas das parcerias interinstitucionais estabelecidas entre os grupos organizadores da obra.

Ao final da leitura da obra os leitores encontram-se frente à necessidade de assumir um compromisso fundamental com o campo da extensão universitária, seja através da promoção de estratégias, da participação em atividades ou ainda do incentivo à extensão. A obra coloca-nos diante da realidade transformadora e potencializadora que a extensão universitária promove nos mais variados contextos, em especial naqueles de periferia. Os casos relatados, discutidos e analisados evidenciam o quanto a extensão vem fazendo a diferença na vida de centenas de milhares de pessoas, dentre os que promovem essas atividades e os que delas são beneficiados. A obra "Reinventar a universidade: extensão universitária com a EJA" nos coloca frente a grandes questões e desafios. Resta, agora, saber o que faremos com eles...

Submetido em: 20/02/2021 Aceito em: 26/02/2021 